\title{
Relationship between attitude towards using new technologies and teaching effectiveness
}

Kant, Ravi \

Maulana Azad National Urdu University, College of Teacher Education, Darbhanga, Bihar, India (edu.ravikant@gmail.com)

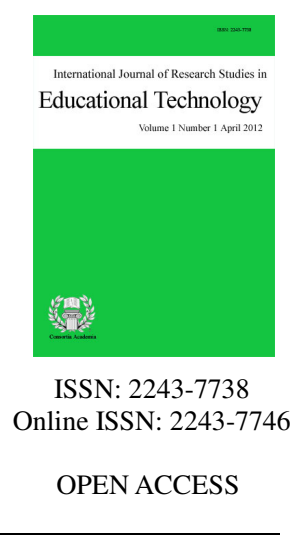

\section{Abstract}

Information and communication technology with the help of engineering gives several tools for helping and enhancing teaching learning process. Technology creates a new and amazing perspective in the field of education. By using new technologies in teaching learning process any teacher can increase their teaching effectiveness. Now those things and activities are possible in the classroom settings with the help of technologies which were rare and impossible to bring in classroom. By taking sample of sixty secondary school teachers with the help of one standardized tools, an attempt has made to explore relationship between attitude towards using new technology and teaching effectiveness. Survey method was used. Study found that there is no significant difference between attitude towards using new technology and teaching effectiveness on the basis of gender and teacher's affiliation board. A positive relationship found between attitudes towards using new technology and teaching effectiveness in male teachers. But in case of female teachers this relationship was insignificant negative. Overall attitude towards using new technology was positively related with teaching effectiveness.

Keywords: uses of new technology; teaching effectiveness; attitude; secondary school teachers 


\section{Relationship between attitude towards using new technologies and teaching effectiveness}

\section{Introduction}

Technology is a major part of today's society and is used in most of our daily activities. It can be a very helpful tool, providing us endless access to information. The most striking innovations in the field on education is the integration of Information and Communication Technology in education. Now we are witnessing two types of explosion viz. population explosion and knowledge explosion. In ancient time expansion of knowledge or information was very limited due to scarcity of media. It was not possible to all person to get latest knowledge and information from the sources which are located at remote location. But by invention of amazing inventions now every information is available on the fingertips of anyone.

Information and communication technology is transforming the field of education radically in every aspects and perspectives. It empowers students to gain wider knowledge in easy way according to their convenience. It also strengthens teacher's capability to make their presentation live and attentive. ICT is also removing the boundaries of distance, language, resources with the help of its tools.

With the help of new technology now teachers are exploring new ideas for teaching and learning. An effective teacher not only imparts the entire educational curricula allotted to him in the best and most efficient manner but also ensures the optimum development of the students. In today's scenario where there is a fierce competition in all spheres of life, effectiveness of the teachers becomes imperative to empower the students to face global challenges. Effective teaching is a par excellence attribute of quality education. There are many factors, which influence the effectiveness of the teacher viz. intelligence, attitude towards teaching, experience, academic qualification, personality, mental health and many others.

Sepehr and Harris, (1995) investigated that the accessibility to suitable software and teachers' tendency to utilize that software have a positive influence on the attitudes of teachers toward the acceptance of technology in their classes. Becker and Riel (1999) explored in their investigation that teachers who have access to enough computers and the required instructional technology at schools possess more positive attitudes toward integrating technology in their classes. According to Daniels (2002) ICTs have become within a very short time, one of the basic building blocks of modern society. New trends in technology are playing a very important role in education sector. Now collection, preservation and dissemination of knowledge is very easy and convenient because of ICT tools. These tools are also making teaching learning process very interesting and conducive. As a living creature every teacher has its own limitations to impart knowledge but with the help of new technologies one can go beyond the limits. Technology integration is the use of technology resources -- computers, mobile devices like smartphones and tablets, digital cameras, social media platforms and networks, software applications, the Internet, etc. in daily classroom practices, and in the management of a school.

According to Baylor and Ritchie (2002), schools successful in integrating technology into their curricula generally work on comprehensive plans for technology use. Rather than acting just as a road map, these plans explain the philosophy of technology use as well as the way of developing teaching-learning activities. Campbell and colleagues (2003) review the research on teacher effectiveness and identify three problems associated with the current concepts of teacher effectiveness. The first problem is the conceptualization of teacher effectiveness itself. The second problem is the relationship between school effectiveness and teaching effectiveness. There could be effective teachers in ineffective schools and ineffective teachers in effective schools, and therefore the relationship between school and teacher effectiveness is becoming problematic.

Kersaint, Horton, Stohl, and Garofalo (2003) stated that positive attitudes of teachers have an effect on the use of technology. They feel more confident and comfortable with technologies and integrate it in their teaching process. Because of the widespread use of computers and internet in educational settings, language teachers are 
Relationship between attitude towards using new technologies and teaching effectiveness

motivated to implement this technology in their classes in order to facilitate language teaching and learning process. Educators are the real representatives of utilizing technologies in language learning (Albirini, 2004). According to Gay and Blads (2005) Information and Communication Technology (ICT) encompasses the effective use of equipment and programs to access, retrieve, convert, store, organize, manipulate and present data and information. While, Kumar and Kaur (2005) state that the current information revolution and increasing impact of information and communication technologies have modernized the process, learning and research in most universities.

Furthermore, in a study by Mcalister, Dunn, and Quinn (2005), teachers showed positive attitudes toward using technology, although they did not have enough experience about technology utilization. The researchers concluded that more time, training, and value should be given to teachers who are as a model for students. Oh and French (2007) found in their study of teacher training programs that teachers obtained more abilities and more confidence with technologies which promoted their attitudes toward technology positively. The integration of technology has also been studied in several Middle Eastern countries. Information and Communication Technology (ICT) plays a vital role in the development of any nation. It has been an instrument for achieving social, economic, educational, scientific and technological development (Adedeji, 2010).

Al Mekhlafi and Al Meqdadi (2010) studied technology integration in K-12 schools in the United Arab Emirates. The authors used a mixed method that included focus groups, interviews, and a questionnaire with a sample of 100 teachers. The findings showed that schools in the UAE were progressive at integrating technology in their classes. The teachers also used a variety of technology tools such as computers with different software, transparencies, the Internet, maps, flyers, and folded papers. Second, there were differences between male and female teachers in regard to the methods of integrating technology; female teachers used different technology tools more than the male teachers. Third, female teachers had more experience, usage, and familiarity of technology tools and applications than male teachers. Fourth, both male and female teachers at UAE Model Schools had high self-perception of their skills and competency to implement technology effectively in their classrooms. Finally, results indicated that both genders highly regarded their competencies in technology implementation.

In Egypt, Bakr (2011) examined the attitudes of Egyptian teachers toward computers. The study sample consisted of 118 public school teachers; 53 males and 65 females. The findings showed that Egyptian public school teachers' attitudes toward computers and computer use were positive. Also, the results showed no significant differences in terms of gender and teaching experience regarding the use of technology. Also, Erdoğan (2011) investigated Turkish primary school teachers' perceptions of school culture of ICT integration in education with a sample of 1,540 primary school teachers. Results showed that the teachers' perceptions of school environments regarding the motivational and technical features were not supportive and negative. Also, results showed that the perceptions of teachers who did not own a personal computer and had little access to the Internet were found to be much more negative toward school ICT culture than those who owned a personal computer and had access to the Internet.

Sweetlin Rajam Amsarani (2000) conducted a study on teacher effectiveness of second language teachers in higher secondary schools. The study used a sample of 50 teachers and 1000 students selected from various higher secondary schools in Nellai District of tamilnadu. The major finding of the study is that Teacher Effectiveness of Post Graduate English teachers is neither low nor high, just moderate; in terms of cognitive aspect is just moderate; in terms of affective and psychomotor aspects it ranges from moderate to low. Amandeep and Gurpreet (2005) conducted a study of teacher effectiveness in relation to teaching competency. The results reveals that female teachers are more effective in their teaching than male teachers; male and female teachers do not differ significantly as far as their teaching competency is concerned; and variable of teaching competency plays significant role in teacher effectiveness of teachers. Shweta Agarwal (2012) conducted a correlation study of teacher effectiveness and job satisfaction of higher secondary school teachers. The study concludes that all types of government school teachers are endowed with more teacher effectiveness than all 
Kant, R.

types of aided and non-aided school teachers, besides finding that government school teachers have better professional and academic knowledge and better relationship with pupils, principles and parents.

Researches of Tondeur, Valcke, and van Braak, 2008, Sang, Valcke, van Braak, and Tondeur, 2010, Akhaba (1999) and Huang and Liaw (2005) explored that if teachers ${ }^{e e}$ attitudes are positive toward the use of educational technology then they can easily provide useful insight about the adoption and integration of ICT into teaching and learning processes. The strong relationship between computer related attitudes and computer use in education has been emphasized in many studies. Attitudes toward computers influence teachers ${ }^{\text {ee }}$ acceptance of the usefulness of technology, and also influence whether teachers integrate ICT into their classroom.

Above researches show different relationship of teaching effectiveness and technology uses. But after carefully observation it is clear that there is a gap of researches between the relationship of teaching effectiveness and technology uses. Keeping this fact in the mind this research was carried out.

\subsection{Objectives of Study}

$>\quad$ To study the attitude towards using new technology of secondary school teachers on the basis of gender and affiliation of school.

$>\quad$ To study the teaching effectiveness of secondary school teachers on the basis of gender and affiliation of school.

$>\quad$ To study the relationship between new technology usages and teaching effectiveness of secondary school teacher on the basis of gender and affiliation of school.

\subsection{Hypotheses}

1. There will be no significant difference between male and female teachers on the scores of ATUNT.

2. There will be no significant difference between teachers affiliated to State board and Central board on the scores of ATUNT.

3. There will be no significant difference between male and female teachers on the scores of teaching effectiveness.

4. There will be no significant difference between teachers affiliated to State board and Central board on the scores of teaching effectiveness.

5. There will be a significant positive relationship between attitude towards uses of new technology and teaching effectiveness of Male teachers.

6. There will be a significant positive relationship between attitude towards uses of new technology and teaching effectiveness of female teachers.

7. There will be a significant positive relationship between attitude towards uses of new technology and teaching effectiveness of state board's teachers.

8. There will be a significant positive relationship between attitude towards uses of new technology and teaching effectiveness of Central board's teachers.

\section{Methodology}

\subsection{Research Method}

In this study normative survey method was deployed for data collection.

\subsection{Population and Sample}

In this study all secondary school teachers working in State board and Central board affiliated school were constituted as population. In this targeted population only 60 teachers were selected as a sample due to some 
limitations of time and resources. Due representation was given to sample.

\subsection{Instruments used}

Attitude towards using new technologies scale (ATUNTS) - This scale was developed by Dr. S. Rajasekar and published by National Psychological Corporation, Agra. This scale consists 30 statements with five point rating scale viz. strongly agree, agree, un-decided, disagree and strongly disagree.

Teacher effectiveness scale (TES) - This scale was developed by Dr. Pramod Kumar and Prof. D.N. Mutha and published by Agra Psychological Research Cell, Agra. This scale consists 69 items with five option to tick viz. totally agree, agree, uncertain, disagree and totally disagree.

\section{Data Analysis and Interpretation}

The main objective of the study is to measure the attitude towards using new technology of secondary school teachers, the teaching effectiveness of secondary school teachers and to know the relationship between using new technology and teaching effectiveness. This study is planned and carried out to test the assumptions and tentative hypotheses which may be accepted or rejected. The analyses have been done in three phases:

$>$ Attitude towards using new technology of secondary school teachers.

$>$ Teaching effectiveness of secondary school teachers.

$>$ Relationship between using new technology and teaching effectiveness of secondary school teachers.

The interpretations of results are discussed simultaneously.

Table 1

ATUNT scores of male and female teachers

\begin{tabular}{llcccc}
\hline \multicolumn{1}{c}{ Variable } & $\mathrm{N}$ & Mean & SD & t & Significance \\
\hline Male & 49 & 106.51 & 14.15 & 0.521 & Not Significant \\
Female & 11 & 103.63 & 8.45 & & \\
\hline
\end{tabular}

Table 1 is showing mean of ATUNT of male and female teachers which are 106.51 and 103.63 respectively. Standard deviations are 14.15 and 8.45 respectively. Calculated t value is 0.521 which is not significant at any level. It is clear by data that male and female teachers do not differ in using new technology. So hypothesis 1 "There will be no significant difference between male and female teachers on the scores of ATUNT" stands accepted. Scores of ATUNT shows that everyone is accepting the importance of technology in education field. Different means of technology are providing ample opportunities to teachers for making their teaching effective.

Table 2

ATUNT scores of State School board and Central School board

\begin{tabular}{llcccc}
\hline Variable & $\mathrm{N}$ & Mean & SD & t & Significance \\
\hline BSEB & 30 & 103.06 & 11.86 & 0.890 & Not Significant \\
CBSE & 30 & 108.90 & 14.16 & & \\
\hline
\end{tabular}

By observing Table 2, mean values of state board and central board school teachers are 103.06 and 108.90 respectively. SD values are 11.86 and 14.16 respectively. Calculated t value is 0.890 which is not significant. So it can be said that affiliating board has nothing to play in aptitude towards using new technology. But because CBSE affiliated teachers has higher mean value so it can be said that central board's teacher has more positive attitude towards using new technologies. So hypothesis 2 "There will be no significant difference between teachers affiliated to State board and Central board on the scores of ATUNT" stands accepted. In India State education boards are suffering from financial crisis. So there is a shortage of technological instruments in 
Kant, R.

comparison to Central education board. Although they are not significant differ.

Table 3

Teaching effectiveness scores of male and female teachers

\begin{tabular}{llcccc}
\hline \multicolumn{1}{c}{ Variable } & $\mathrm{N}$ & Mean & SD & t & Significance \\
\hline Male & 49 & 294.67 & 24.92 & 0.550 & Not Significant \\
Female & 11 & 290.00 & 13.06 & & \\
\hline
\end{tabular}

Glimpses of Table 3 shows that means of male and female teacher's teaching effectiveness are 297.67 and 290.00 and SD are 24.92 and 13.06 respectively. Calculated t value is 0.550 which is not significant at any level. It is clear that male and female teachers do not differ on teaching effectiveness. So hypothesis 3 "There will be no significant difference between male and female teachers on the scores of teaching effectiveness" stands accepted. However there is no significant difference between male and female teachers but high mean scores shows that male are more proactive towards new technology. It may be due to more freeness for male in Indian society. Female are bearing households responsibilities additionally, so they get less time to study or observation of new technology in comparison to male teachers.

Table 4

Teaching effectiveness scores of State School board and Central School board

\begin{tabular}{cccccc}
\hline Variable & N & Mean & SD & t & Significance \\
\hline BSEB & 30 & 296.13 & 20.17 & 0.443 & Not Significant \\
CBSE & 30 & 291.50 & 25.99 & & \\
\hline
\end{tabular}

Data of Table 4 demonstrates the mean values of state board and central board's teachers on teaching effectiveness. Mean values are 296.13 and 291.59 respectively. SDs are 20.17 and 25.99 respectively of both groups. Calculated t value is not significant at any level of significance. So hypothesis 4 "There will be no significant difference between teachers affiliated to State board and Central board on the scores of teaching effectiveness" stands accepted. Teaching effectiveness an acquired phenomenon. State board's teachers are more effective in comparison to Central board's teacher on the basis of mean value. A reason behind this may be that in state board teachers are recruited locally and in central board on national level. So there remains a language problem always which is a very important factor in effective content delivery.

Table 5

Relationship between ATUNT and Teaching effectiveness of Male teachers

\begin{tabular}{lcccc}
\multicolumn{1}{c}{ Variable } & N & Mean & r & Significance \\
\hline ATUNT & 49 & 106.51 & 0.337 & Significant at 0.01 and 0.05 level \\
TE & 49 & 294.67 & & \\
\hline
\end{tabular}

By observation of Table 5 it is clear that obtained $r$ value is positively significant at both level of significance. It means there are a positive relationship between usage of new technology and teaching effectiveness of male teachers. So hypothesis 5 "There will be a significant positive relationship between attitude towards uses of new technology and teaching effectiveness of Male teachers" stands accepted.

Table 6

Relationship between ATUNT and Teaching effectiveness of female teachers

\begin{tabular}{lllcc}
\hline \multicolumn{1}{c}{ Variable } & $\mathrm{N}$ & Mean & $\mathrm{r}$ & Significance \\
\hline ATUNT & 11 & 103.63 & -0.25 & Significant at 0.01 and 0.05 level \\
TE & 11 & 290.00 & & \\
\hline
\end{tabular}


Relationship between attitude towards using new technologies and teaching effectiveness

Table 6 is showing mean of ATUNT of female teachers which are 103.63 and Teaching effectiveness scores is 290.00. Calculated $r$ value is -0.25 which is significant at both level. It is clear by data that there is a significant negative relationship between usages of new technology and teaching effectiveness in case of female teachers. So hypothesis 6 "There will be a significant positive relationship between attitude towards uses of new technology and teaching effectiveness of female teachers" stands rejected.

Table 7

Relationship between ATUNT and Teaching effectiveness of State board's teachers

\begin{tabular}{lcccc}
\hline \multicolumn{1}{c}{ Variable } & $\mathrm{N}$ & Mean & $\mathrm{r}$ & Significance \\
\hline ATUNT & 30 & 103.06 & 0.412 & Significant at 0.01 and 0.05 level \\
TE & 30 & 291.50 & & \\
\hline
\end{tabular}

Data of Table 5 demonstrates the mean values of attitude towards using new technology is 103.06 and teaching effectiveness's mean value is 291.50 of state board's teachers. Calculated $\mathrm{r}$ value is positively significant at any both level of significance. So hypothesis 7 "There will be a significant positive relationship between attitude towards uses of new technology and teaching effectiveness of state board's teachers" stands accepted.

Table 8

Relationship between ATUNT and Teaching effectiveness of Central board's teachers

\begin{tabular}{lcccc}
\hline \multicolumn{1}{c}{ Variable } & $\mathrm{N}$ & Mean & $\mathrm{r}$ & Significance \\
\hline ATUNT & 30 & 108.09 & 0.176 & Not Significant at 0.01 and 0.05 level \\
TE & 30 & 296.13 & & \\
\hline
\end{tabular}

Above table 8 is showing the mean value of ATUNT and Teaching Effectiveness scores of Central board's teachers are 108.09 and 296.13 respectively. Calculated $r$ value is 0.176 which is positive and significant at both level of significance. So hypothesis 8 "There will be a significant positive relationship between attitude towards uses of new technology and teaching effectiveness of Central board's teachers" stands accepted.

\section{Findings and Conclusions}

This research gives a helicopter view on the technology uses and its relationship with teaching effectiveness. This research found that male and female teachers do not differ on the basis of use of technology and teaching effectiveness. It may be because everyone knows that technology plays a very positive role in development of teaching and learning. Both state's and central's board teachers do not differ on these basis. Teaching effectiveness of male teachers found positively related with their uses of technology but in female teachers it is negatively related. One possible reason behind this negative relationship may be that female teacher are bearing more responsibilities than male teacher. So their fatigue may be responsible to negative attitude towards technology.

The findings of Eroldoğan (2007) and Gömleksiz (2004) revealed that teachers are willing to use technology in their courses when technology complies with the curriculum and when appropriate plans regarding effective and constant support in technology use are made. Another dimension prominent in studies based on related literature is that teachers are aware of the importance of educational technology use in courses and that they are not yet willing to use such technologies not only due to lack of the necessary sub-structure for technology use in courses but also due to lack of related support of the school administration and due to insufficient knowledge about use of such technologies in education Findings of Georgina and Hosford (2009); Chen and Chang (2006); Garrison and Bromley (2004); Dexter and Riedel (2003) are consistent with the findings obtained in the present study. It may be concluded that overall use of technology in class is increasing teaching effectiveness of teachers. So it is strongly recommended to increase the use of technology in teaching and learning. 
Acknowledgements - Investigator shows deep thanks to Mr. Tarique Anwer, alumni of MANUU, College of Teacher Education, Darbhanga for his help in collection of data and organizing this research.

\section{References}

Adedeji, O. A. (2010). The development of modern information and communications technology. Ibadan: Creative Educational Publications.

Akbaba, S., \& Kurubacak, G. (1999). Teachers attitudes towards technology. Computers in the Social Studies, $7(2), 833-836$

Al Mekhlafi, A. ,\& Al Meqdadi, F. (2010). Teachers' perceptions of technology integration in the United Arab Emirates School Classrooms. Journal of Educational Technology \& Society, 13(1), 165-175.

Albirini, A. (2004). Teachers' attitudes toward information and communication technologies: The case of Syrian EFL teachers. Computers and Education, 47, 373-398. http://dx.doi.org/10.1016/j.compedu.2004.10.013

Amandeep, \& Gurpreet. (2005). A study of teacher effectiveness in relation to teaching competency. Recent Researches in Education and Psychology, 71(6), 137-140.

Bakr, S. (2011). Attitudes of Egyptian teachers towards computers. Contemporary Educational Technology, 2(4), 308-318.

Baylor, A. L., \& Ritchie, D. (2002). What factors facilitate teacher skill, teacher morale, and perceived student learning in technology-using classrooms? Computers \& Education, 39(4), 395-414. http://dx.doi.org/10.1016/S0360-1315(02)00075-1

Becker, H. J., \& Riel, M. M. (1999). Teacher professionalism, school work culture and the emergence of constructivist-compatible pedagogies. Center for Research on Information Technology and Organizations. Retrieved from http://www.crito.uci.edu/TLC/findings/special_report2/index.htm

Campbell, R., Kyriakides, L, Muijs, R., \& Robinson, W. (2003). Differential teacher effectiveness: Towards a model for research and teacher appraisal. Oxford Review of Education, 29(3), 347-362. http://dx.doi.org/10.1080/03054980307440

Chen, J.-Q., \& Chang, C. (2006). Using computers in early childhood classrooms: Teachers' attitudes, skills, and practices. Journal of Early Childhood Research, 4(2), 169-188. http://dx.doi.org/10.1177/1476718X06063535

Daniels J. S. (2002). Foreword. In Information and communication technology in education-A curriculum for schools and programme for teacher development (pp. 3-4). Paris: UNESCO.

Dexter, S., \& Riedel, E. (2003). Why improving pre-service teacher educational technology preparation must go beyond the college walls. Journal of Teacher Education, 54(4), 334-346.

Erdogan, T. (2011). Turkish primary school teachers' perceptions of school culture regarding ICT integration. Educational Technology Research \& Development, 59(3), 429-443.

Eroldoğan, A. Y. (2007). Primary II: Examine the use of instructional technology, according to some variable levels of subject teachers in grade school [İlköğretim II. kademe okullarındaki branş öğretmenlerinin bazı değişkenlere göre öğretim teknolojilerini kullanma düzeylerinin incelenmesi] (Unpublished Masteral thesis). Çukurova University.

Garrison, M. J., \& Bromley, H. (2004). Social contexts, defensive pedagogies and the (mis)uses of educational technology. Educational Policy, 18(4), 589-613. http://dx.doi.org/10.1177/0895904804266643

Gay, G., \& Blads, R. (2005). Information technology for CXC CSEC. UK: Oxford University Press.

Georgina, D. A., \& Hosford, C. C (2009). Higher education faculty perceptions on technology integration and training. Teaching and Teacher Education, 25(5), 690-696. http://dx.doi.org/10.1016/j.tate.2008.11.004

Gömleksiz, M. (2004). Use of educational technology in English classes. Turkish Online Journal of Educational Technology, 3(2), 71-77.

Huang, H. M., \& Liaw, S. S. (2005). Exploring users attitudes and intentions toward the Web as a survey tool. 
Computers in Human Behaviour, 21(5), 729-743. http://dx.doi.org/10.1016/j.chb.2004.02.020

Kersaint, G., Horton, B., Stohl, H., \& Garofalo, J. (2003). Technology beliefs and practices of mathematics education faculty. Journal of Technology and Teacher Education, 11(4), 549-577.

Kumar, R., \& Kaur, A. (2005). Internet and its use in the engineering colleges of Punjab India. A case study. Webology, 2(4), 1-22.

Mcalister, M., Dunn, J., \& Quinn, L. (2005). Student teachers' attitudes to and use of computers to teach mathematics in the primary classroom. Technology, Pedagogy and Education, 14(1), 77-106.

Oh, E., \& French, R. (2007). Pre-service teachers' perceptions of an introductory instructional technology course. CALICO Journal, 24(2), 253-267.

Sang, G., Valcke, M., van Braak, J., \&Tondeur, J. (2010). Student teachers thinking processes and ICT integration: Predictors of prospective teaching behaviour with educational technology. Computer \& Education, 54, 103-112. http://dx.doi.org/10.1016/j.compedu.2009.07.010

Sepehr, H., \& Harris, D. (1995). Teachers' use of software for pupils with specific learning difficulties. Journal of Computer Assisted Learning, 11, 64-71. http://dx.doi.org/10.1111/j.1365-2729.1995.tb00118.x

Shweta, A. (2012). Correlation study of teacher effectiveness and job satisfaction of higher secondary school teachers. Edutracks, 12(2), 13-16.

Sweetlin, R. A. (2000). Teacher effectiveness of second language teachers in higher secondary schools. Meston Journal of Research in Education, 1(2), 22-25.

Tondeur, J., Valcke, M., \& van Braak, J. (2008). A multidimensional approach to determinants of computer use in primary education: Teacher and school characteristics. Journal of Computer Assisted Learning, 24, 494-506. http://dx.doi.org/10.1111/j.1365-2729.2008.00285.x 
Kant, R. 